\title{
THE INFLUENCE OF STRATEGIC PLANNING AND PERSONNEL COMPETENCE ON ORGANIZATIONAL PERFORMANCE OF THE TNI MATERIAL FEASIBILITY SERVICE MEDIATED BY COMPLIANCE MANAGEMENT
}

\author{
* Sumaryadi ${ }^{1}$, Kusnadi $^{2}$ \\ ${ }^{1}$ Universitas Trisakti, Jakarta, Indonesia \\ ${ }^{2}$ Sekolah Tinggi Manajemen IMMI, Jakarta, Indonesia
}

*Coresponding author.

E-mail addresses: jabriqtea@yahoo.com

\begin{abstract}
ARTICLE INFO
ABSTRACT

Article history:

The main objective of this study is to analyze the effect of strategic planning and personnel competence on organizational performance mediated by compliance

Received: management at the material feasibility service within the Ministry of Defense and the TNI.

20 August 2021

The method used in this research is hypothesis testing using Structural Equation Modeling (SEM) based on Partial Least Square 3.0. The respondent population of this research is

Accepted:

20 September 2021 material feasibility inspectors who have competence and work in the Ministry of Defense and TNI. Sampling with non-probability sampling method and is a saturated sampling with a total of 50 respondents. The results showed that strategic planning had a significant

Available online:

15 November 2021

but insignificant effect on organizational performance, while personnel competence had a significant effect on organizational performance. The mediating role of compliance management has a positive and significant impact on the strategic planning relationship on organizational performance. The results also show that compliance management has a positive and significant influence on the relationship between personnel competence and organizational performance. The variable that has the greatest influence on organizational performance after being mediated by Compliance management is personnel competence. The results of this study provide insight for the organization's material feasibility, in order to improve compliance management so as to improve organizational performance. The novelty in this study is to add to the role of compliance management as a mediating variable in the relationship between strategic planning and organizational performance, and in the relationship between personnel competence and organizational performance. The implication of this research is aimed at helping improve the performance of government organizations in this case the feasibility organization within the Ministry of Defense and the TNI which is tasked with ensuring the safety of personnel and material when defense materials are operated, then compliance management must be fully complied with by personnel at all levels within the organization. The limitation of the research is that it only involves two elements of strategic management, namely strategic planning and personnel competence that affect organizational performance, this becomes an opportunity for further research.
\end{abstract}

Keywords: Strategic Planning, Personnel Competence, Compliance Management and Organizational Performance 


\section{INTRODUCTION}

The Center for Feasibility of the Ministry of Defense of the Republic of Indonesia is an organization tasked with carrying out material feasibility functions, which include elaborating policies, drafting program plans and ratifying military feasibility programs, with the aim of ensuring the safety of personnel and materials when defense materials are used/operated in accordance with the development of science and technology. technology, (Regulation of the Minister of Defense of the Republic of Indonesia No: 12 of 2014).

The important role of the Ministry of Defense's feasibility organization in formulating a military airworthiness strategic plan includes activities to guarantee the feasibility of: defense materials for domestic products/types of products, research and development materials, domestic and foreign procurement materials, production and/or maintenance facilities, construction /facilities/buildings/laboratories, development of airworthiness personnel as military feasibility inspectors and supervisors of the technical functions of the force's military worthiness institutions. Meanwhile, the airworthiness institution in preparing the strategic plan of the airworthiness program includes the following activities: fostering military feasibility and technical supervision of Alutsista and military commodities/defense facilities, carrying out military feasibility activities against Alutsista and other military commodities/defense facilities, (Regulation of the Minister of Defense of the Republic of Indonesia No: 33 year 2014 ).

In addition, to improve the competence of the Indonesian Ministry of Defense's Puslaik personnel, the Ministry of Defense conducts annual routine programs in terms of developing airworthiness personnel as military airworthiness inspectors which include activities, certification of military airworthiness inspectors, certification of marine military airworthiness inspectors, certification of military airworthiness inspectors and dissemination of military airworthiness. The main task of military feasibility inspectors is to carry out activities related to the assessment of the eligibility status of a military commodity, production facility, maintenance facility and other infrastructure to be operated through material verification activities. Material verification is a series of activities carried out by the Military Airworthiness Technical Implementation Team to carry out inspections, tests, and conformity assessments based on the military eligibility standard criteria that have been set and check the functions of all installed systems to be declared "accepted" or "rejected".

Personnel serving as the military feasibility technical implementation team are personnel who have the required qualifications with the following conditions: a. Have attended workshops/courses/training for military feasibility inspectors and skills as required; $b$. have a letter of authorization as evidence of recognition of their qualifications to be involved in the administration of military fitness certification; c. have a background of expertise/qualification in accordance with military commodities, production facilities, and maintenance facilities; and D. master, understand, and understand the regulations and requirements that are directly or indirectly related to the military worthiness certification process. Although the Indonesian Ministry of Defense Puslaik has a strategic role in ensuring the fulfillment of defense material safety requirements when operated, faced with the development of the strategic environment and the rapid advancement of technology in its implementation there are still obstacles.

With this phenomenon, it is hoped that there will be efforts to anticipate through the concept of "Strategic Management" so that the performance of a material feasibility organization like a company in the future must be continuously developed and improved to ensure the fulfillment of regulations and material safety requirements that are in line with the era of globalization and technological advances.

The researcher determined two independent variables, namely "Strategic Planning" and "Personnel Competence" which influenced the dependent variable, arguing that the role of these two variables was very dominant in influencing the performance of the feasibility organization within the Ministry of Defense and the TNI. Strategic planning should be directed at realizing a viable organization with a competitive advantage so that it can improve its performance in certain environmental conditions. Improving the competence of the feasibility inspector is one aspect that determines the success of the feasibility organization. Research by Tsohou and Holtkamp (2017) explains that competence is the knowledge and skills as well as certain attitudes 
that are needed by a person to carry out a task assigned to him in a certain context. organizational performance with variable compliance management as a mediation, especially those discussing the performance of the military feasibility organization.

The concept that will be discussed in this study has two aspects of novelty, namely the influence of strategic planning on organizational performance mediated by compliance management, and the influence of personnel competence on organizational performance mediated by compliance management. The motivation of this research is the development of a model by adding compliance management as a mediating variable in order to maximize strategic planning and personnel competence related to improving the performance of the Military Airworthiness Organization. The general purpose of this research is to provide an overview of the importance of planning aspects and personnel competence supported by Compliance management in order to support organizational performance in the face of strategic environmental developments.

Based on the description of the background of the problem and some previous research results, the researcher considers that strategic planning and personnel competence greatly affect the performance of the material feasibility organization, thus this dissertation is entitled "The Effect of Strategic Planning and Personnel Competence on Organizational Performance mediated by Compliance Management at the Material Feasibility Service. TNI".

Referring to the background and previous research literature, the formulation of the problem of this research is whether Strategic Planning has a positive and significant effect on Organizational Performance? Does the competence of personnel have a positive and significant effect on Organizational Performance? Does Strategic Planning have a positive and significant effect on Compliance management? Does the competence of personnel have a positive and significant effect on Compliance management? Does Compliance management have a positive and significant effect on organizational performance? Does strategic planning have a positive and significant effect on organizational performance through Compliance management? Does the competence of personnel have a positive and significant impact on organizational performance through Compliance management?

\section{LITERATURE REVIEW}

\section{Strategic Planning}

The strategic planning of an organization is strongly influenced by the dynamics of the development of the strategic environment that often changes, some literature emphasizes that environmental uncertainty and turbulence are very decisive variables in the strategic planning of an organization, Bolisani and Bratianu (2017). In order for organizational goals to be achieved, direction is needed in formulating and implementing strategies, this is in accordance with the opinion of Wheelen $\mathrm{T}$ (2015) that strategic planning is long-term planning concerned with developing the company's mission, goals, strategies, and policies that begin with the process of analyzing the environmental situation. external and internal. Elliott et. al, (2019) stated that strategic planning is a set of concepts, procedures, tools and organizational resources used in determining strategic direction to achieve organizational goals. Donkor (2018) states that strategic planning is a real input for the organization and has the ability to accelerate organizational performance. Based on a review of some of the literature above, it can be concluded that strategic planning is basically a series of organizational long-term planning activities involving vision, mission and goals with a review of organizational resources and environmental conditions, in order to achieve a superior performance.

\section{Personnel Competence}

According to McClelland in Shaheen (2018), competence is defined as the basic characteristics possessed by a person that have a direct effect on, or can predict, excellent performance. According to Spencer in Ismail (2019) Competence is the basic characteristics possessed by individuals including aspects: a. Knowledge; b. Skills : c. Personality. Hertanto (2017) Competence is the main variable that must be owned by an employee in carrying out his work. Qinghua $\mathrm{Hu}$ (2018) knowledge-based employee competence in e-commerce affects individual 
performance and has a significant positive effect on organizational performance. Based on a review of some of the literature above, it can be concluded that personnel competence is a person's capacity which includes knowledge, skills, attitudes and fighting power in completing a job or task in accordance with what has been determined by the organization.

\section{Organizational Performance}

Organizational performance is the level of achievement of results in order to realize organizational goals, the achievement of organizational performance which is the accumulation of performance of all individuals can be explained through assessment and measurement. This is supported by the research of Alosani et. al, (2019) which states that organizational performance is a series of achievements obtained on a job after implementing a series of work practices. Further research by Habibin et. al, (2015) stated that performance measurement is used to help organizations identify organizational strengths and weaknesses. Vasconcelos ( 2017 ) Company performance is measured through company age, company size and company innovation. Sabiu (2018) performance appraisal is a process in which managers examine and evaluate employees comparing them to predetermined standards.

Alosani ( 2019 ) In order to achieve the best overall organizational performance it is necessary to apply strategic planning and innovative practices to the Police Agency in Dubai. Pollanen (2016) Organizational performance will be better with the use of Strategic Performance Measure in every strategic decision making. Based on a review of some of the literature above, it can be concluded that organizational performance is the level of achievement of results or it can also be an accumulation of performance from all personnel involved in an organization.

\section{Compliance Management}

Compliance management is an organizational monitoring process to ensure that all rules and norms can be complied with by all employees and leaders that have an impact on organizational performance, this is supported by Dudek's research (2019) which states that Compliance management is an audit and consulting activity related to the organization's global legal environment., which includes preventive and corrective measures, support of the organization in legal action, and development of procedures that impact legal liability and the image of the organization. WU ( 2016 ) Compliance management is an activity that includes the development, implementation, establishment of mechanisms, cultural inculcation and prevention of compliance risk. Benedek (2012) Compliance management is an initiative to prevent errors and violations of the law with the aim of detecting and preventing corporate crimes and errors, minimizing and preventing the recurrence of problems, improving business processes and controls, ideally Compliance management can help personnel at all levels to operate an organization. without finding incidents of non-compliance. Based on a review of some literature and previous research, it can be concluded that Compliance management is a management activity in the form of supervision of the organization to ensure that organizational behavior from the leadership level to the subordinate level always complies with all applicable laws and social norms.

\section{Conceptual Framework}

Based on the formulation of the problem, the research developed consists of four variables which are stated in the conceptual framework picture as follows: 


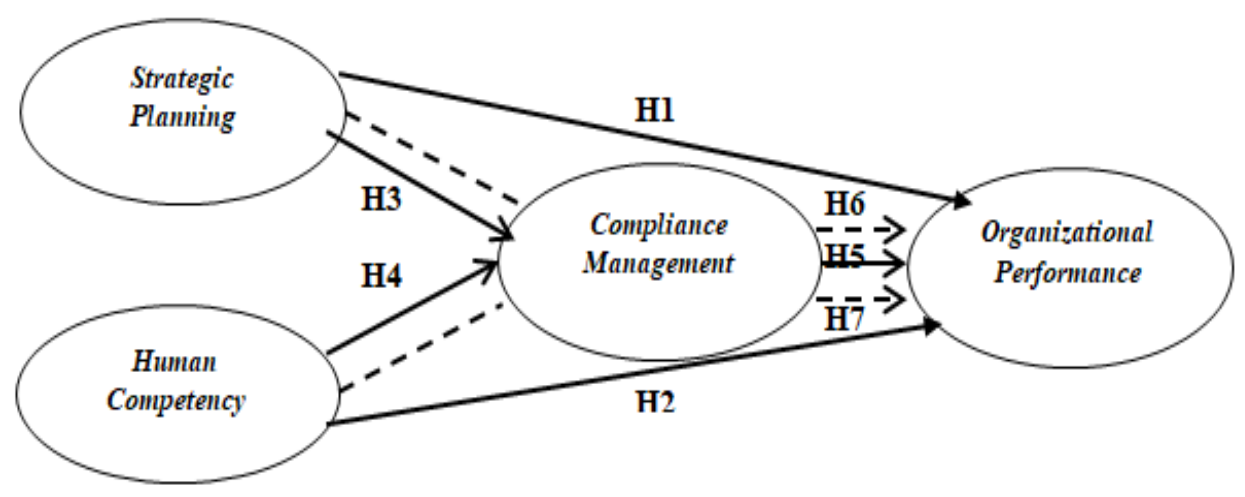

Figure 1. Conceptual Framework

\section{Hypothesis Development}

The development of hypotheses in this study include: H1: Strategic Planning has a positive and significant impact on Organizational Performance. H2: Competence of personnel has a positive and significant impact on organizational performance. H3: Strategic Planning Has a positive and significant impact on Compliance management. H4: Competence of personnel has a positive and significant effect on Compliance management. H5: Compliance management has a positive and significant effect on organizational performance. H6: Strategic Planning has a positive and significant impact on organizational performance through Compliance management. H7: Personnel Competence has a positive and significant impact on organizational performance through Compliance management.

\section{METHODS}

Research design. The variables tested include strategic planning and personnel competence (independent variable), organizational performance (dependent variable) and compliance management (mediating variable). The time dimension of the research is cross sectional. Method of collecting data. In this study, the population used as respondents is TNI officers who meet the requirements and have competence as material feasibility inspectors and are assigned to the military feasibility service at the Indonesian Ministry of Defense Airworthiness Center, the TNI-AD Airworthiness Service, the TNI-AL Airworthiness Service and the TNI Airworthiness Service. -AU. The sample in this case is the material feasibility inspector at the Indonesian Ministry of Defense, the Army Airworthiness Service, the Naval Airworthiness Service and the Air Force Airworthiness Service. The sample used in this study is a saturated sample of 50 respondents.

Data analysis method. The data analysis method uses the Smart PLS software version 3.0, which is a variant-based structural equation analysis (SEM) that can simultaneously test the measurement model as well as test the structural model. The validity and reliability test was used SPSS, while the structural model was used to test causality (testing hypotheses with predictive models). There are several reasons why PLS is used in research. In this study, the reasons are that PLS is a data analysis method based on the assumption that the sample does not have to be large, that is, the number of samples less than 100 can be analyzed.

\section{RESULTS AND DISCUSSION}

\section{Hypothesis Test}

The criteria for accepting or rejecting the hypothesis are based on the t-statistics value $<1.96$, (degree of error 5\%), then the hypothesis is rejected (Hair, 2010). The results of the t-statistics value of the Smart PLS output from the results of testing the seven hypotheses according to the problem formulation are as follows: 
a) Testing the influence of the Strategic Planning variable on Organizational Performance (H1) obtained a regression coefficient value of 0.071 , with a t-statistics value of 0.676 . The value of $t$-statistics $<1.96$, then Strategic Planning has a positive but not significant effect on Organizational Performance. So the hypothesis which states that Strategic Planning has a positive and significant effect on Organizational Performance is rejected.

b) Testing the influence of the Personnel Competence variable on Organizational Performance (H2), obtained a regression coefficient value of 0.224 , with a t-statistics value of 2.323 . The value of t-statistics $>1.96$, then Personnel Competence has a positive and significant effect on Organizational Performance. So the hypothesis which states that Personnel Competence has a positive and significant effect on Organizational Performance is accepted.

c) Testing the influence of the Strategic Planning variable on Compliance management $(\mathrm{H} 3)$, the regression coefficient value is 0.397, with a t-statistics value of 3.138. The value of t-statistics > 1.96, then Strategic Planning has a positive and significant effect on Compliance management. So the hypothesis which states that Compliance management has a positive and significant effect on Compliance management is accepted.

d) Testing the influence of the Personnel Competence variable on Compliance management (H4), obtained a regression coefficient value of 0.322 , with a t-statistics value of 3.260 . T-statistics value $>1.96$, then Personnel Competence has a positive and significant effect on Compliance management. So the hypothesis which states that Personnel Competence has a positive and significant effect on Compliance management is accepted.

e) Testing the influence of the Compliance management variable on Organizational Performance (H5) obtained a regression coefficient value of 0.703 , with a t-statistics value of 7.620. T-statistics value > 1.96, then Compliance management has a positive and significant effect on Organizational Performance. So the hypothesis which states that Compliance management has a positive and significant effect on Organizational Performance is accepted.

f) Testing the influence of the Strategic Planning variable on Organizational Performance through Compliance management (H6) obtained a regression coefficient value of 0.279 , with a t-statistics value of 2.513. The value of t-statistics > 1.96, then Strategic Planning has a positive and significant effect on Organizational Performance through Compliance management. So the hypothesis which states that Strategic Planning has a positive and significant effect on Organizational Performance through Compliance management, is accepted.

g) Testing the influence of the Personnel Competence variable on Organizational Performance through Compliance management (H7) obtained a regression coefficient value of 0.226 , with a t-statistics value of 3.213. T-statistics value >1.96, then Personnel Competence has a positive and significant effect on Organizational Performance through Compliance management. So the hypothesis which states that Personnel Competence has a positive and significant effect on Organizational Performance through Compliance management, is accepted.

\section{Discussion}

a) The Effect of Strategic Planning on Organizational Performance

The findings from this study can explain that although the Feasibility Organization has a written plan regarding its long-term goals, has a written plan on organizational strategy, has a procedure for detecting / anticipating errors on an ongoing basis, has an effort to take into account factors outside the immediate environment of the organization, but it will not necessarily be able to improve organizational performance. Thus, this study is not in line with previous studies conducted by Kadri (2014), Suwono (2018) and Ray (2018), whose research results show that Strategic Planning has a positive and significant effect on Organizational Performance, in contrast to the results of this research which explained that Strategic Planning has a positive but not significant effect on Organizational Performance.

b) The Influence of Personnel Competence on Organizational Performance 
The findings of this study can be explained that, if a personnel has the will to increase work motivation, is able to control emotions, is tenacious in completing work, has confidence in his abilities, always has a positive attitude towards problems, always tries to be able to understand each problem, is able to master the field of knowledge. related to work, have innovation in work, and are able to use and optimize facilities related to their work, then Organizational Performance can be improved. So that the leadership must pay attention to the increase in the competence of the personnel above, if they want to improve organizational performance. Thus, this study is in line with various previous studies such as those conducted by Ngo, et al., (2014), Hendrawan, et al., (2018), and Shet (2018).

c) The Effect of Strategic Planning on Compliance Management

The results of testing the third hypothesis provide empirical evidence that Strategic Planning carried out by the Organization will affect Compliance management, so that all members of the organization will be effective at work because they rarely waste time at work, carry out as much work as possible that can be carried out all the time, will always try to come to work on time regardless of circumstances or situations, to always produce high-quality work in accordance with the main task, be mentally ready to work when you arrive at work, be very careful to follow work procedures and instructions so that opportunities make zero mistakes, and work with an attractive and appropriate personal appearance in accordance with the applicable provisions as a military airworthiness inspector. Thus, this study is in line with previous research conducted by Masyhur (2013).

d) The Influence of Personnel Competence on Compliance Management

The results of testing the fourth hypothesis regarding Personnel Competence proved to have a positive and significant effect on Compliance management. The results of this test show that if the personnel have the will to increase work motivation, emotional control, tenacity in completing work, confidence in their abilities, positive attitude towards problems, understanding of problems, mastery of work-related knowledge areas, having innovation in work, and being able to When using facilities related to work, these personnel will be more obedient, so that they have qualified, effective and efficient personnel in implementing Compliance management. The results of this study are in line with previous studies conducted by Vanni (2018), Konwea et al. (2018), and Tsohou and Holtkamp (2018).

e) The Influence of Compliance Management on Organizational Performance

Compliance management is proven to have a positive and significant impact on Organizational Performance in this study. The results of this study recommend that if all members of the organization or personnel in the ranks of the Indonesian Ministry of Defense feasibility center, the TNI-AD Airworthiness Service, the TNI-AL Airworthiness Service and the TNI-AU Airworthiness Service, in their work are able not to waste time while working, carry out work as much as possible at all times, always tries to come to work on time regardless of the circumstances or situations, always produces high quality work in accordance with the main task, is mentally ready to work when he arrives at work, is very careful If you are careful to follow work procedures and instructions so that there are zero chances of making mistakes, and work with an attractive and appropriate personal appearance in accordance with the provisions as a military feasibility inspector, then organizational performance will automatically be achieved well, because research proves this effect. The results of this study are in line with previous studies conducted by Busse and Doganer (2018) illustrating that the introduction of compliance and ethics programs in companies has a positive impact on employee acceptance and organizational performance. Likewise with the research results of Hadasch et al. ( 2015 ), Muntaha (2019), and Razi ( 2017 ).

f) The Effect of Strategic Planning on Organizational Performance through Compliance Management

The results of the sixth hypothesis test show that Compliance management mediates the effect of strategic planning on organizational performance, which is proven to be positive and significant. Thus, the results of this study are in line with previous studies conducted by Arifin (2017), Azis (2016), Pangarso and Susanti (2016) concluded that compliance has a significant effect on organizational performance. The results of this test show that in order to achieve and improve the performance of the organization's 
Eligibility, the strategic planning carried out by the organization must go through the implementation of Compliance management. Because this study explains that strategic planning is not able to directly affect the achievement of organizational performance.

g) The Influence of Personnel Competence on Organizational Performance through Compliance Management

Compliance management mediates the effect of personnel competence on organizational performance, where the results are proven to be positive and significant. This means that it is in line with various previous studies conducted by Yulia et al. (2020), Supriyanti (2019), and Kusmeilia et al. (2019) has shown that knowledge or competence of a person (personnel) has an effect on compliance. Furthermore, other research shows that employee (personnel) compliance has a positive and significant influence on organizational performance (Rohmah, 2019), as well as (Saputra and Heryanto, 2019). These results indicate that the competence of personnel is able to provide a positive and significant influence on organizational performance, directly or indirectly mediated by Compliance management. This shows that the main factor that can support organizational performance at the appropriateness center ranks of the Indonesian Ministry of Defense, Airworthiness Service of the TNI-AD, TNI-AL, TNI-AU is the Competence of the Personnel of the Feasibility Inspector.

\section{CONCLUSION AND SUGGESTION}

\section{Conclusion}

Based on the results of the study, general conclusions can be drawn as follows:

a) Strategic planning has a positive but not significant effect on organizational performance. This finding proves that the respondents consider the Strategic Planning variable to make a weak contribution to the achievement of Feasibility Organizational Performance at the Ministry of Defense and the TNI, which is formed by the strategic management process.

b) Personnel Competence is proven to have a positive and significant impact on Organizational Performance. This finding proves that the respondents consider the personnel competency variable to make a strong contribution to organizational performance, so that material feasibility organizations can guarantee defense material safety requirements, military feasibility inspectors are needed who have the competence "Mastery of the use of facilities/tools related to work" in dealing with duties as inspector of material feasibility in the field.

c) Strategic Planning has a positive and significant impact on Compliance management. This finding proves that the respondents consider the strategic planning variable to make a strong contribution to Compliance management. So that compliance management can be implemented, the feasibility organization must have a written strategic plan regarding its long-term goals.

d) Competence of personnel has a positive and significant impact on Compliance management. This finding proves that the higher the knowledge, attitudes and skills of the personnel in the material feasibility organization, the higher the compliance management will be.

e) Compliance management is proven to have a positive and significant impact on Organizational Performance. This finding proves that the Compliance management variable in terms of "Prudence in following work procedures" which is understood and obeyed by all levels in the organization contributes greatly to the achievement of material feasibility organizational performance.

f) Compliance management has a positive and significant mediation function between Strategic Planning and Organizational Performance. This finding proves that the mediating effect of compliance management has a positive and significant effect on the strategic planning relationship on organizational performance. Thus, to improve the performance of the organization's feasibility in ensuring the fulfillment of defense material safety, the strategic planning made by the organization must implement compliance management. 
g) Compliance management has a positive and significant mediation function between Personnel Competence and Organizational Performance. This finding proves that the mediating effect of compliance management has a positive and significant effect on the relationship of personnel competence to the performance of the organization's feasibility. Thus, improving the performance of the feasibility organization in ensuring the fulfillment of defense material safety can be achieved if the competence of the airworthiness personnel carries out compliance management.

\section{Research Limitations}

This research is inseparable from several limitations, especially in terms of time, besides that this research also has limitations, including:

a) The study only discusses two elements of strategic management, namely strategic planning and personnel competence as independent variables on organizational performance, excluding other variables that also greatly affect the feasibility of organizational performance.

b) The sample of this research is only material feasibility inspectors from the Ministry of Defense of the Republic of Indonesia, the Indonesian Army, the Navy and the Air Force, so research with wider involvement is still needed if you want to get an overall panorama.

\section{Theoretical Implications}

Based on the research findings, the theoretical implications can be described as follows:

a) The results of this study reveal that the strategic planning variable does not significantly affect organizational performance directly. The implication is that even though the organization has a strategic plan, it will not necessarily improve its organizational performance.

b) The results of this study reveal that the competence of personnel positively and significantly affects the performance of the organization directly. The implication is, if you want to improve organizational performance, it is necessary to improve the competence of personnel.

c) The results of this study reveal that Compliance management positively and significantly affects organizational performance directly. The implication is that if you want to improve organizational performance, it is necessary to improve compliance management.

d) This study shows that Compliance management has a role in mediating the effect of strategic planning on organizational performance. The implication is that if you want to improve organizational performance, it is necessary to improve strategic planning through Compliance management.

e) This study shows that Compliance management has a role in mediating the influence of personnel competence on organizational performance. The implication is that if you want to improve organizational performance, it is necessary to improve the competence of personnel through Compliance management.

\section{Managerial Implications}

In order for an organization to improve its performance in terms of productivity, service quality, responsiveness, responsibility and accountability, every organization must pay attention to the main factors that affect organizational performance, namely strategic planning, personnel competence and compliance management.

a) Strategic planning. In preparing the strategic plan, it is hoped that the organization will have a commitment to be able to respond quickly to the dynamics of changing strategic environments and the development of technological advances which are then written down in the organization's vision.

b) Competence of personnel. Material feasibility inspectors are expected to understand that "The ability to master the use of work-related facilities" is a key competitive advantage that must be maintained and developed in order to improve organizational performance.

c) Compliance management. Organizations need to consider aspects of compliance management in the implementation of strategic planning so as to improve organizational performance. 
d) Organizations are expected to consider aspects of compliance management in managing human resource competencies to improve organizational performance. Competence Human resources will be better able to respond to technological developments when the organization adheres to the principles of Compliance management.

e) Compliance management is expected to be fully complied with by all levels in order to improve organizational performance. A material feasibility organization with a high level of performance can be achieved if all levels in the organization comply with both mandatory and self-regulation regulations, thus the level of material safety during operation will be more reliable.

\section{Suggestions For Future Researchers}

Future research is expected to be able to explore variables that are directly related to the achievement of improving the performance of the feasibility organization in order to ensure the material safety of the defense equipment so that the "Zero accident" program can be realized. Suggested variables:

1) Incorporating technology variables (Sagieva and Kotsemir 2018; Zanjirchi et al, 2019) as variables that greatly affect the performance of the organization's feasibility.

2) Lifting several variables that were not examined in this research, but these variables are suspected to greatly affect organizational performance, such as: value system (Escofet and Rosanas, 2019), organization culture (Fakhar, et al., 2012), social innovation process (Vézina et al.2018), strategic management information system (Ghazmahadi, Basri, Kusnadi and Ramli, 2020), Organizational Culture (Armanda, Basri, Kusnadi and Ramli, 2020).

\section{REFERENCES}

Ahmad ( 2016 ). The effect of competency, motivation, and Organizational culture on the employee performance At the Jayakarta hotel, Bandung, Indonesia. Journal of Business on Hospitality and Tourism. Vol 02 Issue 1, 136-146.

Alijoyo ( 2019 ). National risk management survey 2019, Center for Risk Management Studies Indonesia. http://www.crmsindonesia.org.

Alosani, M. S., Yusoff, R., \& Al-Dhaafri, H. (2019). The effect of innovation and strategic planning on enhancing organizational performance of Dubai Police. Innovation \& Management Review, 2-24.

Amrollahi, A., \& Rowlands, B. (2017). Collaborative open strategic planning: a method and case study. Information Technology and People, 30(4), 832-852.

Aprikristanti ( 2020 ). The influence of organizational culture and competence on performance through the motivation of civil servants in the education office of Probolinggo Regency. UNIBA Surakarta National Seminar 2020. ISBN. 978-979-1230-65-0.

Arasa Robert and Peter K'Obonyo (2012). The Relationship between Strategic Planning and Firm Performance. International Journal of Humanities and Social Sciences. Vol. 2 Nov No. 22.

Arifin Muhammad ( 2017 ). Change management strategy in improving Discipline in higher education. EduTech Journal. Vol. 3 No. 1.

Ariansyah ( 2017 ). Related application strategy of low self esteem with Compliance patients running Adl in RSJD Atma Husada Mahakam samarinda. https://scholar.google.co.id.

Armanda, YZ Basri, Kusnadi, AH Ramli (2020). The influence of strategic policy and strategic leadership on the performance of organizations mediated by organizational culture work safety and health. International Journal of Creative Research and Studies: vol:4(1), 40-47.

Armstrong M with Stephen Taylor ( 2020 ). Handbook of Human resources Management practice. 15th Edition, British Library Catalouging in publication data.

Ataunur, I., \& Ariyanto, E. (2015). The influence of competence and training on the performance of PT Adaro energy tbk employees. Business Review (Vol. 16). 
Angelina Febrita ( 2017 ). The effect of tax planning and taxpayer morality on tax compliance. Scientific Journal of Students, Faculty of Economics and Business, Universitas Brawijaya. Vol 5, No 2 .

Baridwan ( 2014 ). Determinants of tax planning and corporate taxpayer compliance behavior. Journal of Multiparadigm Accounting. Vol 5 August No. 2 Pages 170-344.

Benedek Petra (2012). Compliance Management, a New Response to Legal and Business Challenges. Acta Polytechnica Hungarica Vol. 9, No. 3.

Biegelman with Daniel R. Biegelman (2008). Building a World Class Compliance Program Best Practices and strategies for success. 1st Edition, New Jersey : John Wiley \& Son, Inc.

Bleker and Dick Hortensius (2014). The development of a global standard on compliance management. Baltzer Science Publishers 02/2014.

Bolisani, E., \& Bratianu, C. (2017). Knowledge strategy planning: an integrated approach to manage uncertainty, turbulence, and dynamics. Journal of Knowledge Management, 21(2), 233-253.

Bryson, J., Edwards, L. H., Bryson, J., \& Edwards, L. H. (2017). Strategic Planning in the Public Sector. Oxford Research Encyclopedia of Business and Management, Vol 1-March -27.

Busse and Ufuk Doganer ( 2017 ). The role of compliance for organizational change Qualitative evidence from German SMEs. Journal of Organizational Change Management, Vol. 31 No. 2, pp. 334-351.

Chouhan V \& Sandeep Srivastava ( 2016 ). Understanding Competencies and Competency Modeling, A Literature Survey. Journal of Business and Management. Vol 16, Issue 1. PP 14-22.

Comptroller's Handbook ( 2019 ), Corporate and Risk Governance Version 2.0. Office the Comptroller's of the currency. https://www.occ.gov.

David FR, Forest R David ( 2017 ). Strategic Management, A competitive advance approach, concepts and cases. Fiveteenth edition, Pearson Education, Inc.

Dobija D, Anna Maria Górska, Giuseppe Grossi, Wojciech Strzelczyk ( 2018 ). Rational and symbolic uses of performance measurement Experiences from Polish universities. Accounting, Auditing \& Accountability Journal Vol. 32 No. 3, pp. 750-781.

Doherty, N. F., Tajuddin, S. T., \& Doherty, N. F. (2018). Towards a user-centric theory of value-driven information security compliance. Journal of Information Technology \& People. Vol. 31 No. 2, pp. 348-367.

Donkor, J., Donkor, G. N. A., \& Kwarteng, C. K. (2018). Strategic planning and performance of SMEs in Ghana. Asia Pacific Journal of Innovation and Entrepreneurship, 12(1), 62-76.

Dudek, D. (2019). The significance of compliance in customer relations is illustrated by the example of PGE. Annales Universitatis Mariae Curie-Skłodowska, 53(1), 29.

Elbanna, Said, Andrews, Rhys William and Pollanen, Raili ( 2016 ). Strategic planning and implementation success in public service organizations: evidence from Canada. Public Management Review 18(7) , $1017-1042$.

Elliott, G., Day, M., \& Lichtenstein, S. (2019). Strategic planning activity, middle manager divergent thinking, external stakeholder salience, and organizational performance: a study of English and Welsh police forces. Public Management Review, 00(00), 1-22.

Escofet and Josep M. Rosanas ( 2019 ). Trust under bounded rationality: competence, value systems, unselfishness and the development of virtue. Maig, vol. 15, nm. 1, p. 1-21.

Esthi Maharani ( 2018 ). The burning and sinking of KRI Rencong-622 in the waters of Sorong. https://www.republika.co.id (accessed October 14, 2019).

Esfahani Parvaneh, Ali Mohammad Mosadeghrad and Ali Akbarisari ( 2018 ). The success of strategic planning in health care organizations of Iran. International Journal of Health Care Quality Assurance Vol. 31 No. 6, pp. 563-574.

Fadol, Y., Barhem, B., \& Elbanna, S. (2015). The mediating role of the extensiveness of strategic planning on the relationship between slack resources and organizational performance. Management Decisions, 53(5), 1023-1044. 
Falshaw, J., Glaister, K. and Tatoglu, E. (2006), "Evidence on formal strategic planning and company performance", Management Decision, Vol. 44 No. 1, pp. 9-30.

Fakhar S, Luqman, R. A., Khan, A. R., \& Shabbir, L. (2012). Impact of organizational culture on organizational performance: An overview. Interdisciplinary Journal of Contemporary Research in Business, 3(9), 975-985.

Fitri Haryanti Harsono ( 2018 ). The incident of the Tank sinking in the Bogowonto River, Purworejo, Central Java. https://www.liputan6.com (accessed October 15, 2019).

George, B., Walker, R. M., \& Monster, J. (2019). Does Strategic Planning Improve Organizational Performance? A Meta-Analysis. Public Administration Review, 79(6), 810-819.

Germano, M. A., Stephenson, S. M. S., \& Germano, M. A. (2013). Strategic value planning for libraries. https://doi.org/10.1108/08880451211256405.

Ghazmahadi, YZ Basri, Kusnadi, AH Ramli (2020). The influence of strategic management information system, strategic partnership on organizational performance mediated by organizational culture in occupational safety. International Journal of Creative Research and Studies : Vol 4(1), 32-39.

Ghozali ( 2014 ). Structural Equation Modeling, alternative method with Partial least square (PLS). 4th edition . Semarang : Undip publishing body.

Gorgoń Monika, Konrad Raczkowski and Felix Kraft ( 2019 ). Compliance Risk Management in Polish and German Companies. Journal of Intercultural Management. Vol. 11 | No. 4 pp. 115-145.

Greenley, G. and Okemgil, M.A. (1998), "Comparison of slack resources in high and low performing British companies", Journal of Management Studies, Vol. 35 No. 3, pp. 377-398.

Hadasch F, Shirley Gregor and Alexander Maedche (2015). The influence of directive explanations on users' business process compliance performance. Business Process Management Journal. Vol. 22 No. 3, pp. 458-483.

Habidin, N. F \& Mohd Fuzi, N. (2016). Strategic systems, and organizational performance for automotive suppliers. International Journal of Lean Six Sigma, 7(2), 110-135.

Hair, J F,, Anderson, R E., Black W. C (2010). Multivariate Data Analysis. Upper Saddel River, New Jersey : Prentice Hall Inc.

Haliah, H., \& Nirwana, N. (2019). The development of good governance model for performance improvement. International Journal of Excellence in Government, 1(1), 21-36.

Hendrawan, A., Yulianeu, A., \& Cahyandi, K. (2018). The influence of competence on team performance. journal of management : 2(1), 143-150.

Hanif, M. (2018). Shar ah-compliance ratings of the Islamic financial services industry: a quantitative approach. International Journal of Islamic Finance, Vol. 10 No. 2, pp. 162-184.

Hertanto ( 2017 ). Competency theory of human resource management. Journal of HR Management 2017.

Hoffman, T. (1999), "The meaning of competency", Journal of European Industrial Training, Vol. 23 No. 6, pp. 275-285.

Hourneaux F, São Paulo, Dolores Amalia Gallardo-Vázquez ( 2018 ). Triple bottom line and sustainable performance measurement in industrial companies. Revista de Gestão, Vol. 25. 4, pp. 413-429.

Huber G ( 2015 ). Performance measurement effects on organizational responses to threats. Measuring business excellence. Vol. 19 pages 32.

Hu Qinghua ( 2018 ). Analysis on the Impact of Knowledge-based Employees' Competency on Performance in E-commerce Enterprises. Advances in Economics, Business and Management Research, volume 68.

International standard ISO 1960 ( 2014 ) . Compliance management systems Guidelines. Published in Switzerland . http://www.iso.org.

Ismail K, Muhd Khaizer Omar, Arnida Abdullah ( 2019 ). Professional Management Competency for TVET Teachers in Engineering Faculty at Vocational College. International Journal of Academic Research in Progressive Education and Development, 8(4), 33-46. 
Jain Shri M.K. ( 2019 ). Regulatory and Supervisory Expectations on Compliance Function in Banks. The Annual Global Banking Conference organized by IBA and FICCI, Mumbai, August 20, 2019.

Kadir (2015). Applied Statistics: Concepts, examples and data analysis using SPSS and Lisrel programs in research. 2nd Edition. Jakarta : Rajawali Press.

Kadri alfin ( 2014 ). The influence of the strategic environment, organizational culture, and strategic planning on the performance of the Padang city government. Journal of Accounting, Vol. 5 No. 2 .

Kalia and Bhawana Bhardwaj ( 2019 ). Contextual and Task Performance: Do Demographic and Organizational variables matter ?. Rajagiri Management Journal Vol. 13 No. 2, pp. 30-42.

Karlsson, F., Karlsson, M., \& ström, J. (2017). Measuring employees' compliance with the importance of value pluralism. Information \& Computer Security, Vol. 25 Issue: 3, pp.279-299.

Kasozi and Charles Brandon ( 2017 ). Mapping Compliance to Organizational Performance in Statistical Work. The National Graduate School of Quality Management 2017.

Keerthy T Ra and Biju M Kb ( 2020 ). The Mediating Role of Citizenship Behavior in the Development of Competency Based Performance. Our Heritage journal. Vol-68- January Issue-1.

Kim, H., \& Lee, C. W. (2018). Efficiency analysis for nonprofit organizations using DEA Focused on humanitarian assistance organizations in South Korea. Asia Pacific Journal of Innovation and Entrepreneurship. Vol. 12. 2. pp. 165-180.

Knox and Simon Neighbor ( 2017 ). Food safety compliance Approaches Case study of a primary authority Partnership between E.H. Booths Ltd And Preston City Council. British Food Journal, Vol. 119 No. 4, pp. 744-758.

Kolibačova gabriela. ( 2014 ). The Relationship Between Competency and Performance. Acta Universitatis Agriculturae et Silviculturae Mendelianae Brunensis, 62(6): 1315-1327.

Konwea, Funmilayo Alice David, Seyi Elizabeth Ogunsile ( 2018 ). Determinants of compliance with child immunization among mothers of children under five years of age in Ekiti State, Nigeria. Journal of Health Research. Vol. 32 No. 3, pp. 229-236.

Kusmeilia Rifa Renia, Cahyaningsih, Kurnia ( 2019 ). Effect of Tax Knowledge, Application of E-Filing System and Application of E-Billing System on Taxpayer Compliance. Journal of Accounting, Auditing and Accounting Information Systems), Vol. December 3 No. 3 .

Kourtzidis, S. (2018). Investigating the determinants of firm performance insurance companies performance. https://doi.org/10.1108/EJMBE-09-2018-0094.

Kwarteng, Barbara Osman, and Jacob Donkor ( 2019 ). Innovative low-cost strategy and firm performance of restaurants The moderation of competitive intensity. Asia Pacific Journal of Innovation and Entrepreneurship, 2398-7812.

Kylaheiko, K., Puumalainen, K., Sjögrén, H., Syrjä, P., \& Fellnhofer, K. (2016). Strategic planning and firm performance: A comparison across countries and sectors. International Journal of Entrepreneurial Venturing, 8(3), 280-295.

Loh, K. L., \& Yusof, S. M. (2019). Blue ocean leadership activities improve firm performance. International Journal of Lean Six Sigma, 2040-4166.

Mas'ud F (2004). Organizational Diagnostic Survey, concept and Application. First Edition. Diponegoro University Publishing Agency.

Mamun Abdullah and Syed Ali Fazal, (2018) "Effect of entrepreneurial orientation on competency and microenterprise performance", Asia Pacific Journal of Innovation and Entrepreneurship, Vol. 12 Issue: 3, pp.379-398.

Marwanto and Riyadi (2014) The Influence of Compensation and Work Environment on the Motivation and Work Discipline of Soldiers in the KRI X Fleet's Eastern Region Work Unit. Journal of Economics \& Management Sciences. Vol. 1 No.1, April. matter. $74-82$.

Marx, T. G. (2015). The impact of business strategy on leadership. Journal of Strategy and Management, 8(2), 110-126. 
Masyhur Hadi (2013). Effect of modern tax administration system on taxpayer compliance. Journal of Management \& Business Science. Vol. 04, March No. 01.

Mbiti, A. M., Arasa, R. M., \& Kinyili, J. M. (2019). Influence of Performance Appraisal on Performance of Universities in Machakos and Kitui Counties, Kenya. European Journal of Business and Management Research, 4(5), 85-91.

Meissner, M. H. (2018). Accountability of senior compliance management for compliance failures in a credit institution. Journal of Financial Crime, 25(1), 131-139.

Meyer, M. A. (2019). Competencies required for healthcare improvement positions. International Journal of Health Care Quality Assurance, 32(1), 281-295.

Michael E Porter (1998). Competitive strategy Techniques for Analyzing Industries and Competitors. First Edition, The Free press a Division of Simon \& Schuster Inc.

Muhammad Hafil ( 2014 ). The cause of the explosion of the Indonesian Navy's ammunition depot in Tanjung Priok is suspected to be TNT. https://www.republika.co.id (accessed October 12, 2019).

Muhammad Taufiqqurahman ( 2018 ). The sinking of the Indonesian Army's fast motorboat on Pramuka Island. https://news.detik.com (accessed November 14, 2019).

Muntaha, H. (2019). Analysis of the Effect of Obedience and Compensation on Employee Performance at the Pontianak City Regional Secretariat Office. Assets, Vol. 21 , March, p. 19-24.

Ngo, H., \& Loi, R. (2014). Linking HRM competency to firm performance: an empirical investigation of Chinese firms. https://doi.org/10.1108/PR-05-2013-0086.

Nkundabannyanga, S. K., Nakyeyune, G. K., \& Muhwezi, M. (2019). Management mechanisms, deterrence measures and public finance regulatory compliance in Uganda. Journal of Public Budgeting, Accounting and Financial Management, 31(2), 178-19.

Omondi Peter and Ochieng ( 2019 ). Financial performance trends of United States Hockey Inc: a resourcedependency approach. Journal of Economics, Finance and Administrative Science. Vol. 24. 48, pp. 327-344.

Oyewobi, L. O., Windapo, A. O., Rotimi, J. O. B., \& Jimoh, R. A. (2016). Relationship between competitive strategy and construction organization performance: The moderating role of organizational characteristics. Management Decisions, 54(9), 2340-2366.

Pangarso Astadi and Putri Intan Susanti (2016) The effect of work discipline on employee performance in the basic social service bureau of the regional secretariat of West Java Province. Journal of Theoretical and Applied Management Vol 9. No. 2.

Paramaduhita and Elia Mustikasari (2018). Non-employee individual taxpayer compliance Relationship with income and perception of taxpayer. Asian Journal of Accounting Research. Vol. 3 No. 1, pp. 112-122.

Pearce II JA and Richard B. Robinson Jr ( 2018 ). Strategic management, Formulation, Implementation and Control. 12th edition. McGraw-Hill Education Asia.

Regulation of the Minister of Defense of the Republic of Indonesia No: 12 of 2014, concerning the Principles of Material Development of State Defense within the Ministry of Defense and the Indonesian National Armed Forces.

Regulation of the Minister of Defense of the Republic of Indonesia No: 33 of 2014, concerning the Implementation of Military Eligibility to support national defense.

Pham, H. and Ha Viet Hoang ( 2019 ). The relationship between organizational learning capability and business performance The case of Vietnam firms. Journal of Economics and Development Vol. 21 No. 2, pp. 259-269.

Pires V and Guilherme Trez ( 2018 ). Corporate reputation A discussion on construct definition and measurement and its relation to performance. Revista de Gestão. Vol. 25:1, pp. 47-64.

Pollanen, R., Abdel-Maksoud, A., Elbanna, S., \& Mahama, H. (2017). Relationships between strategic performance measures, strategic decision-making, and organizational performance: empirical evidence from Canadian public organizations. Public Management Review, 19(5), 725-746. 
Poovathingal, J. S., \& Kumar, D. V. (2018). Quantifying the contribution of competencies toward performance. International Journal of Productivity and Performance Management, 67(4), 693-716.

Prayogi Muhammad Andi, Muhammad Taufik Lesmana and Lukman Hakim Siregar ( 2019 ). The Influence of Communication and Work Discipline to Employee Performance. Advances in Social Science, Education and Humanities Research, volume 343.

Prikshat, V., Biswas, K., Nankervis, A., \& Hoque, M. R. (2018). Bangladesh HR professionals' competencies: Impact on firm performance and moderating effects of organization life cycle. Evidence-Based HRM, 6(2), 203-220.

Puspitasari, Supri Wahyudi Utomo, Elva Nuraina (2017). Influence of leadership style, compensation and work environment on employee work discipline. Accounting Education Scientific Forum - PGRI Madiun University. Vol. 5 No. October 1 , Pg. 146-160.

Raymundus (2018). Strategic management planning and job satisfaction on employee performance. Business Management Journal. Vol.14 (No. 2) : 75 - 153.

Razi R F ( 2017 ). The effect of compliance with laws and regulations, the use of information technology, accounting control and competence of the regional apparatus on the performance accountability of government agencies. JOM Fekon Vol. 4 No. 1.

Reid, M. F., Brown, L., McNerney, D., \& Perri, D. J. (2014). Time to raise the bar on nonprofit strategic planning and implementation. Strategy and Leadership, 42(3), 31-39.

Ressy ( 2018 ). The influence of the internal control system and work motivation on the performance of government agencies with public accountability as an intervening variable. (Unpublished).

Rizaldy W and Agus Setiawan ( 2015 ). Competence and quality of employee services for aviation safety. Journal of Transportation and Logistics Business Management, Vol.1 January No 2.

Rohmah and Alini Gilang ( 2020 ). The Influence of Work Discipline On Employees Performance at the Office of the Regional Civil Service Agency of West Java Province. e-Proceeding of Management : Vol.6, No.1 April Page 1087.

Ryan, G., Spencer, L. M., Bernhard, U., \& Spencer, L. M. (2019). Development and validation of a customized competency-based questionnaire. An International Journal, Vol. 19 Issue: 1, pp.90-103.

Sabiu, Kabiru Jinjiri Ringim, Tang Swee Mei, Mohd Hasanur R Joarder ( 2018 ). Relationship between human resource management practices, ethical climates and organizational performance, the missing link An empirical analysis. PSU Research Review, Vol. 3 No. 1, pp. 50-69.

Sadress, Juma Bananuka, Laura Orobia and Julius Opiso (2018). Antecedents of tax compliance of small business enterprises: a developing country perspective. International Journal of Law and Management. Vol. 61 1, pp. 24-44.

Sagieva, G., \& Kotsemir, M. (2018). Measuring technological level of organisations: methodological approaches and assessment. Foresight, 20(4), 416-442.

Salge, T.O. and Vera, A. (2013), "Small steps that matter: incremental learning, slack resources and organizational performance", British Journal of Management, Vol. 24 No. 2, pp. 156-173.

Salmah Muslimah ( 2016 ). List of TNI Aircraft Accidents in the Last 12 Years since 2004-2015. https://news.detik.com (accessed October 16, 2019).

Samei, H., \& Feyzbakhsh, A. (2015). Predecessors competency framework for nurturing successors in family firms. International Journal of Entrepreneurial Behavior and Research, 21(5), 731-752.

Saputra, I. \& Heryanto. (2019). The Effect Of Competence And Organizational Climate On Discipline And Its Impact On Performance Of Country Civil Apparatus In The Regional Financial Agency Of District, Dharmasraya. Archives of Business Research, 7(8), 76-89.

Septiani Maulya, Bambang Swasto Sunuharyo, Arik Prasetya (2016) The effect of organizational commitment on work discipline and employee performance. Journal of Business Administration. Vol. 40, Nov. No. 2 . 
Seate, B. M., Pooe, R. I. D., \& Chinomona, R. (2016). The relative importance of managerial competencies for predicting the perceived job performance of Broad-Based Black Economic Empowerment verification practitioners. SA Journal of Human Resource Management, 15, 1-12.

Sekaran, U., \& Bougie, R (2013). Research Methods for Business. 6th Edition. West Sussex : John wiley \& sons Ltd.

Shaheen M, MD Sikandar Azam, Mahesh Kumar Soma and T. Jagan Mohan Kumar ( 2018 ). A competency framework for contractual workers of the manufacturing sector. Industrial and commercial training, vol. 51 no. 3 2019, pp. 152-164.

Shet, S. V., Patil, S. V., \& Chandawarkar, M. R. (2019). Competency based superior performance and organizational effectiveness. International Journal of Productivity and Performance Management. https://doi.org/10.1108/IJPPM-03-2018-0128.

Sillanpää, V. (2011, November). Performance measurement in welfare services: A survey of Finnish organisations. Measuring Business Excellence, Vol. 15, pp. 62-70.

Silverman (2008). Compliance Management for Public, private on non-profit organization. 1st edition. New York, McGraw-Hill eBooks.

Sinkovics Noemi, Samia and Rudolf R. Sinkovics ( 2016 ). Rana Plaza collapse aftermath : are CSR compliance and auditing pressures effective ?. Accounting, Auditing \& Accountability Journal . Vol. 29 No. 4, pp. 617-649.

Sotiriadis, M. D. (2015). Culinary tourism assets and events: suggesting a strategic planning tool. https://doi.org/10.1108/IJCHM-11-2013-0519.

Steinberg RM (2011) Governance, Risk management and Compliance Management. 1st edition. New Jersey : John Wiley \& Sons Inc.

Sudaryono ( 2019 ). Research Methods Quantitative, Qualitative and Mix Method. 2nd edition. Depok : Rajawali pers.

Supriyanti and Nurhidayati ( 2019 ). The effect of tax knowledge and perception of taxpayers on taxpayer compliance. Journal of accounting and Information Technology. Vol 7 no 1 May, 41-50.

Susilo Leo J ( 2017 ). Governance, Risk Management and Compliance, Executive's Guide to risk Governance and risk oversight. 1st Edition. PT. Grasindo Jakarta.

Susilo W, Moedjiman, Luluk Sumiarso and I Made Dana Tangkas ( 2018 ). National Competency System Based on the Indonesian National Qualifications Framework and Indonesian National Work Competency Standards. 1st Edition, Yogjakarta : Andi Offset.

Sutrisno, S. (2013). The purpose of this study was to examine the effect of labor discipline and motivation to work on the performance of the civil servant in the Office of Social Service of Central Java Province. Scientific journal of economic and business dynamics Vol. 1 April No. 1.

Suwono ( 2018 ). The influence of strategic planning and strategic implementation on the performance of regional water companies, Tirta Wijaya, Cilacap Regency. Journal of Management and Economics. vol. 1. June no. 2 .

Taufiqurokhman ( 2016 ). Strategic Management. 1st Edition, Jakarta : Prof. University. Dr. Moestopo Religion.

Switzer Carole S., Anil Suri, Gaurav Kapoor, Valeh Nazemoff (2013). Governance, Risk Management, and Compliance: Creating the Right GRC Strategy for Your Company. Exec Blueprints. http://www.books24x7.com.

Thakur, R., Hale, D., Alsaleh, D., Thakur, R., Hale, D., \& Alsaleh, D. (2018). Manager's report: organizational culture \& strategy association. https://doi.org/10.1108/FS-02-2018-0015.

The institute of company secretaries of india ( 2019 ). Professional programme, Governance, risk management, compliances and ethics. http://www.icsi.edu.

Tsohou, A., \& Holtkamp, P. (2018). Are users competent to comply with information security policies? An analysis of professional competence models. Information Technology and People, 31(5), 1047-1068. 
Triastuti Dinie Anisa ( 2018 ). The influence of work environment, competence and organizational climate on employee performance. journal of management Review . Volume 2 Number 2 Page (203-208).

Umrani, W. A., Kura, K. M., \& Ahmed, U. (2018). Corporate entrepreneurship and business performance. PSU Research Review, 2(1), 59-80.

Vanni, D. (2017). The role of compliance in the Italian banking system. Journal of Financial Crime, 24(1), 143-147.

Vasconcelos R and Marcos Oliveria ( 2017 ). Does innovation make a difference ? An analysis of the performance of micro and small enterprises in the foodservice industry. Innovation \& Management Review Vol. 15. 2, pp. 137-154.

Veliu, L., \& Manxhari, M. (2017). The impact of managerial competencies on business performance: sme's in kosovo. Vadyba Journal of Management, 1(30), 59-65.

Vezina Martine, Majdi Ben Selma, Marie Claire Malo( 2019). Exploring the social innovation process in a large market based social enterprise A dynamic capabilities approach. Management Decision, https://doi.org/10.1108/MD-01-2017-0090.

Verhage Antoinette ( 2016 ). Great expectations but little evidence: policing money laundering. International Journal of Sociology and Social Policy :Vol. 37 No. 7/8, pp. 477-490.

Vicente and Miguel Mira da Silva ( 2019 ). A Conceptual Model for Integrated Governance, Risk and Compliance. https://www.researchgate.net/publication.

Waal, A., \& Meingast, A. (2017). Applying the high performance organization framework in the horticulture and greenhouse sector. Measuring Business Excellence, 21(2), 136-151.

Wheelen, Thomas L and J. David Hunger (2015). Strategic Management And Business Policy, Fourteenth edition. New Jersey : Pearson Education, Inc.

Wibowo ( 2017 ). Work management. 5th Edition, Depok : Rajawali Press.

Wolf, C., \& Floyd, S. W. (2017). Strategic Planning Research: Toward a Theory-Driven Agenda. Journal of Management (Vol. 43).

WU Xue-jing and Hong-li liang ( 2016 ). Preliminary Analysis on Problems and Countermeasures of Compliance Management in China's Banking Industry. International Conference on Education, Training and Management Innovation, ISBN: 978-1-60595-395-3.

Xiu L, Xin Liang, Zhao Chen and Wei Xu ( 2017 ). Strategic flexibility, innovative HR practices, and firm performance A moderated mediation model. Personnel Review Vol. 46. 7, pp. 1335-1357.

Yulia, Ronni Andri Wijaya, Desi Permata Sari, M. Adawi (2020). The effect of tax knowledge, taxpayer awareness, education level and tax socialization on taxpayer compliance in MSMEs in the city of Padang. Journal of economics and information management. Volume 1, March, Issue 4.

Yoshikuni, A. C., \& Albertin, A. L. (2018). Effects of strategic information systems on competitive strategy and performance. International Journal of Productivity and Performance Management, 67(9), 20182045.

Yusuf, I., \& Ekudayo, D. (2018). Regulatory non-compliance and performance of deposit money banks in Nigeria. Journal of Financial Regulation and Compliance, 26(3), 425-441.

Yue Ngo Hang, Chun-Yan Jiang, Raymond Loi (2014). Linking HRM competency to firm performance: an empirical investigation of Chinese firms. Personnel Review. Vol. 43 No. 6, pp. 898-914

Zanjirchi, S. M., Jalilian, N., \& Shahmohamadi Mehrjardi, M. (2019). Open innovation: from technology exploitation to creation of superior performance. Asia Pacific Journal of Innovation and Entrepreneurship, 13(3), 326-340.

Zeng, S.Z. (2019). Research on Competitive Strategy-Case of DDL Construction Company. American Journal of Industrial and Business Management, 9, 743-763.

Zuana Erfina, Patricia Dhiana Paramita and Rita Andini (2018). The effect of tax service quality and tax service competence on taxpayers by mediating taxpayer awareness. Journal of Accounting. 
Zuhdi, M., Suryadi, D., \& Yuniati, Y. (2019). The effect of modernization of the administrative system and tax sanctions on individual taxpayer compliance at KPP Pratama Bandung x. MEA Scientific Journal (Management, Economics, \& Accounting), 3(1), 116-135. 